\title{
The Legal, Historical and Industrial Context of Underwater Heritage: Introduction
}

\author{
Hans Peeters, Geoff Bailey, and Nena Galanidou
}

\begin{abstract}
Interactions between commercial and industrial exploitation of the seabed and archaeological and scientific investigation have been at the heart of developments in the understanding of Europe's submerged landscapes and prehistory since at least the early twentieth century. This introduction considers some of the ways in which that relationship has evolved since that time, including the adoption of international laws under the aegis of United Nations Conventions, the development of close relationships between Dutch fishermen operating beam-trawl fishing nets in the North Sea and a network of private collectors specialising in Pleistocene fossils and artefacts, the imposition of European Union regulations on offshore industrial projects to include monitoring of underwater archaeology and palaeoenviron-
\end{abstract}

H. Peeters $(\bowtie)$

Groningen Institute of Archaeology, University of

Groningen, Groningen, the Netherlands

e-mail: j.h.m.peeters@ rug.nl

G. Bailey

Department of Archaeology, University of York, York, UK

College of Humanities, Arts and Social Sciences, Flinders University, Adelaide, SA, Australia

e-mail: geoff.bailey@york.ac.uk

N. Galanidou

Department of History and Archaeology, University of Crete, Rethymno, Greece

e-mail: galanidou@uoc.gr ments and most recently the incorporation of seabed mapping and underwater cultural heritage in the European Union's 2020 Blue Growth agenda. These developments have played an important role in the growth of knowledge about the underwater cultural heritage notwithstanding the potentially destructive effects of offshore industrial activity. The impact of economic growth and industrial exploitation in the coastal zone, coupled with sea-level rise, is likely to intensify the threats to the underwater cultural heritage in the coming decades, posing new challenges as well as opportunities in the further development of relationships between industrial operators, government agencies and scientific and archaeological researchers.

\section{Keywords}

Beam-trawl fishing · Blue Growth ·

Environmental impact assessment .

International law $\cdot$ Underwater cultural

heritage $\cdot$ UNESCO convention

\subsection{Introduction}

One of the major objectives of the SPLASHCOS (Submerged Prehistoric Archaeology and Landscapes of the Continental Shelf) network as set out in its original Memorandum of Understanding in 2009 was to promote the field 
of submerged prehistoric archaeology and landscapes to heritage professionals, government agencies, commercial organisations, policy makers and a wider public, as well as to the wider community of professional archaeologist and scientists, and to encourage cross-border integration and collaboration in this aspect of the underwater cultural heritage. To that end, a variety of activities were organised and documents produced including guidance on the relationship between marine industry and submerged prehistoric archaeology (Satchell 2013) a major workshop held at Esbjerg in 2013 with the North Sea offshore industry: 'Offshore Industry and Archaeology: A Creative Relationship', a variety of other dissemination activities, new projects and publications (see in particular Satchell 2017; Tidbury et al. 2017; Missiaen et al. 2017), the production of a major position paper for the European Marine Board, the advisory group for European marine policy in all its many dimensions (Flemming et al. 2014), and contributions to international workshops, notably a session on Maritime Heritage and Blue Growth at the European Maritime Day held at Athens in June 2015 Full details are available on the SPLASHCOS website (https:// www.splashcos.org/).

Some indication of the ways in which the underwater cultural heritage $(\mathrm{UCH})$ is managed and the national and regional institutions responsible for research and management is given in the preceding chapters, most of which have sections on the management of UCH. Many chapters refer to the threat posed by the expansion of offshore industrial and commercial activity, especially commercial fisheries, drilling for oil and gas, extraction of aggregates, development of infrastructure for renewable energy such as wind farms, construction of harbours, tunnels and bridges, and laying of pipelines and cables on the seabed. In some areas, changes in the marine environment, whether resulting from climate change or pollution, are an added threat to the survival of underwater remains. These threats are of course, double-edged, because engineering works can lead to the exposure and discovery of submerged landscapes and archaeology that would otherwise have remained deeply buried and out of sight, as well as to their destruction. Some chapters provide examples of important archaeological discoveries that have resulted from cooperation with industry, notably in Denmark, Germany, Norway, the Netherlands and Britain (Bailey et al., Chap. 3, this volume; Jöns et al., Chap. 5, this volume; Glørstad et al., Chap. 6, this volume; Peeters and Amkreutz, Chap. 8, this volume; Bailey et al., Chap. 10, this volume).

Most countries discussed in this volume are members of the European Union, and much of the regulatory framework for $\mathrm{UCH}$ has been developed at European level with a series of EU directives on the management of $\mathrm{UCH}$ in relation to offshore industries. The EU is also responsible for other initiatives which take a basin-wide and continent-wide approach intended to ensure sharing of good practice across State borders and supports the development of a unified cross-border approach, for example, in the mapping of offshore geology and bathymetry, and notably in the mapping of the underwater cultural heritage through the SPLASHCOS Viewer. The need for robust and well-informed regulations for the management and protection of the $\mathrm{UCH}$ is everpresent and likely to grow.

The purpose of this section is to bring together a group of three chapters that focus in more detail on the legal, regulatory and historical issues that inform the relationship between research, offshore industrial activities and government agencies concerned with UCH. All three chapters are the result of presentations originally given at the Esbjerg conference of 2013 referred to above. We begin with the universally applicable framework of international legal principles that informs all governmental regulations and offshore industrial activity (Dromgoole, Chap. 25, this volume). The remaining chapters offer two national case studies, which provide insights, respectively, into the regulatory framework in the UK and the licensing regime for offshore industrial activity (Pater, Chap. 26, this volume), and the long history of mutual dependency and co-evolution of interests in the Netherlands between trawler fishermen, private collectors and the acquisition of 
new knowledge about the submerged landscape (Maarleveld, Chap. 27, this volume). Here, we summarise the key themes and add some additional commentary on the Blue Growth agenda of the EU, which is providing an important driver for the integration of all these interests in policies for sustainable growth and management of maritime interests on Europe's coasts.

Three themes recur throughout these discussions. The first is the explicit recognition that submerged prehistoric landscapes and archaeological remains on and beneath the seabed are an important part of the underwater cultural heritage (along with shipwrecks, airplanes and other sort of cultural materials of later periods), and this is increasingly acknowledged in the formal wording of national and international treaties, plans, policies and legislation. The second is the productive relationship that can develop between commercial and scientific interests despite the potentially destructive impact of offshore activity. The third is the degree of inter-relationship between the management and protection of the underwater cultural heritage, especially the prehistoric component, and that of the natural environment. At the same time, there are clearly unresolved ambiguities and uncertainties at the boundaries between different jurisdictions, and ongoing political sensitivities and tensions between commercial and scientific objectives.

\subsection{The Legal Framework}

The starting point for this discussion is the 1982 United Nations Convention on the Law of the Sea (LOSC) and the 2001 United Nations Convention on the Protection of the Underwater Cultural Heritage (UCHC). The LOSC has achieved very nearly universal ratification (by 168 States, notable exceptions in the European arena being Turkey and Israel (see http://www.un.org/depts/ los/reference_files/status2018.pdf). The UCHC came into force in 2009 and has so far been ratified by 61 States including many of the coastal states in southern Europe (see http://www. unesco.org/eri/la/convention.asp?KO=13520\&la nguage $=E \&$ order $=$ alpha). Notable exceptions relevant to this volume are Israel, Turkey and Greece in the south-east, and Ireland, the UK, the Netherlands, Denmark, Germany, Sweden and Norway in the north-west, although important principles of UCHC are incorporated in European Union (EU) regulations and the national policies of most of these States. There are also general principles of international law that are applicable.

Dromgoole (Chap. 25, this volume) sets out the issues at stake, highlights the definitions in law of terms such as the 'continental shelf, 'territorial waters', and the 'exclusive economic zone' (EEZ), clarifies what they do or do not cover in terms of $\mathrm{UCH}$ and draws attention to the gaps in legal coverage and how these can be addressed.

One of the principal difficulties with the LOSC is that the Articles relating to $\mathrm{UCH}$ (namely, Articles 149 and 303) were originally intended to regulate the intentional removal of underwater cultural heritage such as the looting of shipwrecks, rather than the possibility of inadvertent damage to $\mathrm{UCH}$ by industrial activities, and it is the latter which is of greatest relevance to submerged prehistoric remains. Moreover, these LOSC Articles only apply to certain areas of the sea. The distinction between 'intentional removal' of UCH and 'inadvertent damage' remains an important one in law as well as a source of ambiguity.

According to the LOSC, every State has full legal rights over what takes place within its own territorial waters, defined as the area out to a 12-mile limit ${ }^{1}$ from coastal baselines, and over its own flag vessels when they travel beyond that limit. Article 303 also allows States to declare a contiguous zone extending out for a further 12 miles (i.e. to the 24-mile limit from coastal baselines) and imposes a general duty on States to cooperate in this zone but only with respect to the removal of $\mathrm{UCH}$, not to inadvertent damage to $\mathrm{UCH}$ by industrial activity.

${ }^{1}$ Throughout this discussion, the term 'mile' refers to the nautical mile, equivalent to 1.15 miles or $1.852 \mathrm{~km}$ (see also Dromgoole, Chap. 25, this volume). 
Beyond the 24-mile limit, the LOSC allows certain rights over the continental shelf but only with respect to natural resources. In law the continental shelf is defined as the area extending out to 200 miles from coastal baselines, regardless of the physical width of the continental shelf (or beyond 200 miles for States that have a very wide physical continental shelf) or to the mid-point of the shelf between States that share the intervening waters of a shallow sea, such as the States around the borders of the North Sea.

Article 149 of the LOSC also defines a zone called 'the Area' which lies beyond the limit of the continental shelf and is beyond the jurisdiction of any one State. Article 149 specifies that objects of archaeological and historical interest in that zone should be preserved. This provision clearly refers to an area of seabed that is too deep to be of relevance to submerged prehistory and can only apply to sunken wrecks of ships and planes or cultural objects lost overboard in transit. States can also declare the area from the 12-mile limit out to the edge of the continental shelf as an EEZ, but this only gives rights over natural resources and specifically excludes cultural materials on or beneath the seabed.

The result of this legislation is a jurisdictional 'gap' between the 24-mile outer limit of the contiguous zone and the outer limit of the continental shelf. It was filling this gap that originally motivated the creation of the $2001 \mathrm{UCHC}$. The Articles of the UCHC set out important principles, including a definition of the $\mathrm{UCH}$ as 'all traces of human existence having a cultural, historical or archaeological character which have been partially or totally under water, periodically or continuously, for at least 100 years' (Article 1), a definition that covers shipwrecks as well as submerged prehistoric remains, and treasure hunting as well as inadvertent damage. Other principles are the obligation to report cases of $\mathrm{UCH}$, to preserve the $\mathrm{UCH}$, with in situ preservation as the first option in cases of potential damage, and promotion of training, public access and cooperation between States. Many States have not yet ratified the UCHC, mainly because of political sensitivities about imposing restrictions on economically important activities on the continental shelf, and there remain 'constructive ambiguities' in some of its provisions that are open to different interpretation and the creation of loopholes for avoiding regulation.

Nevertheless, as Dromgoole points out, States that have not yet ratified the UCHC do have various legal methods at their disposal under international law and the LOSC, both direct and indirect, over activities relating to $\mathrm{UCH}$ in the jurisdictional gap. These include control of the activities of the flag vessels of the State in question when operating beyond territorial waters, and regulation of foreign companies that are exploiting natural resources through national and EU regulations governing the provision of licences for offshore activity.

A succession of EU directives has imposed legal requirements on EU member States by specifying the need to include consideration of $\mathrm{UCH}$ in environmental impact assessments that have to be carried out in advance of offshore development projects (Salter et al. 2014; Jöns et al., Chap. 5, this volume). Also to be mentioned in this context is the 1992 Valletta Convention for the Protection of the Archaeological Heritage of Europe of the Council of Europe, which includes submerged prehistory. But this Convention does not carry the same legal force as international treaties or EU directives and applies only within the 12-mile limit of territorial waters.

What the UCHC does is to impose a legal duty to make full use of existing regulatory methods. In practice, many States that have not yet ratified the UCHC apply these methods, and an example of how this works in a national context is provided by Pater (Chap. 26, this volume). Nevertheless, the ratification of the UCHC would give force to the management and protection of the UCHC in those States that have not yet ratified it.

\subsection{Licensing and Regulation of Offshore Developments}

Environmental impact assessments (EIAs) in advance of major offshore work and regulation and monitoring of their implementation are now enshrined in EU (European Union) legislation. 
Moreover, the legislation explicitly includes underwater archaeological heritage. Pater (Chap. 26, this volume) examines how this process works in the UK (English) context to regulate and promote the relationship between commercial activity and the management of the UCH.

In the UK the term 'environment' is now widely used to include the 'historic environment', which refers to all interactions between people and places over time and to all surviving physical remains of past human activity whether visible, submerged or buried. Physical remains are referred to as 'heritage assets', and their significance is judged in relation to their heritage interest, whether archaeological, architectural, artistic or historic. Historic England (HE) is the UK government department responsible for the marine and terrestrial historic environment and carries out various functions in that capacity. In the marine sphere, it provides strategic oversight over areas of the marine environment associated with offshore industrial development and commissions specialist reports to assess the current state of the art in the investigation of submerged cultural remains in their sedimentary and palaeoenvironmental context. It provides advice to offshore developers, planning authorities responsible for granting licences for industrial development and archaeological consultants employed by both types of organisation. It can impose conditions on licences to ensure that mitigation work is carried out appropriately, that any palaeoenvironmental and archaeological data are collected to professional standards, that reporting procedures are adhered to and that technical reports are archived in a publicly accessible repository. HE also delivers or commissions training programmes to ensure continuing professional development in relation to new developments in archaeology and related disciplines. The actual funding of the environmental impact assessment that precedes the granting of a licence, and any follow-up work once the development is approved, is the responsibility of the developer.

The first step in a licence application is for the industrial company to appoint archaeological consultants to provide a desk-based EIA, which will assess the likely potential impact of the development work on known or anticipated heritage assets in light of current knowledge. This document is usually produced in consultation with HE and is accompanied by a Written Scheme of Investigation (WSI), which sets out desk-based sources of information, methodologies for the interpretation of geophysical data and the specific methods of data collection that will inform archaeological interpretation, once licence consent has been granted. These documents are reviewed by professional archaeological consultants employed by the planning authority and $\mathrm{HE}$, and they will also draft the final report once work is completed.

Pater's outline of course presents the UK (English) approach. However, comparable approaches exist elsewhere, notably in the Netherlands, Denmark and Germany (Bicket et al. 2014; Salter et al. 2014). Moreover, given the similar context of offshore industrial activity in the North Sea, joint initiatives involving crossborder collaboration in developing the research base are clearly desirable. One example of such an initiative is the North Sea Prehistory Research and Management Framework (Peeters et al. 2009), which has facilitated close collaboration between researchers and heritage professionals in the UK and the Netherlands. However, sustained collaboration has proved difficult to maintain, not so much because of differences of national perspective but rather because of a fragile dependency on dedicated individuals (Salter et al. 2014).

In principle, the regulatory processes described above provide a strong framework for ensuring proper consideration of the UCH in offshore developments and the monitoring and implementation of data collection to professional standards. However, a regulatory framework can only ever be as good as the manner in which it is implemented in practice in given circumstances and must inevitably be vulnerable to commercial and central government pressures to minimise costs and delays. Counterbalancing that tendency is the publicity and public interest that can come with proper attention to archaeological and palaeoenvironmental discoveries made during commercial operations and an enhanced reputation 
for the companies involved for community engagement and sustainable management of seabed resources. Moreover, the cost of mitigation work is often a very small fraction of the total budget for large offshore projects and easily accommodated provided that the archaeological and palaeoenvironmental research in question is built into the work plan of the offshore development at an early stage (see Satchell 2013 for a general overview, and Peeters and Amkreutz, Chap. 8, this volume, and Moree and Sier 2015 for the Yangtze Harbour project).

\subsection{The History of Fishing Technology and Its Archaeological Impact}

A different perspective on the relationship between commercial and scientific interests is illustrated by the history of beam-trawl fishing in the Netherlands. Here voluntary agreements between private collectors and industrial operators, particularly trawler fishermen but also in more recent decades companies that excavate sand and gravel aggregates, have evolved over a long period outside the legal and regulatory framework discussed above. The beam trawl has been widely used by the Dutch fishing fleet in the North Sea since early in the twentieth century. Originally devised for inshore shellfishing, it was later extended to offshore trawling from the 1950s onwards. The technique is ideally suited to flat, sandy surfaces and involves dragging a solid beam along the seabed that disturbs the surface and collects everything in its path, but it is also highly damaging. Beam-trawl fishing, despite its destructive tendencies, has resulted in many important discoveries in the North Sea, especially remains of extinct fauna (Glimmerveen et al. 2004, 2006; Mol et al. 2006; Van Kolfschoten and Van Essen 2004. Peeters and Amkreutz, Chap. 8, this volume), resulting in one of the largest collections of offshore finds known anywhere and on a scale unmatched in comparison with the fishing industries of Ireland, the UK, France or Belgium. What is less well-known is the history of the relationship between Dutch fishermen and the collection of fossils and antiquities. Maarleveld (Chap. 27, this volume) examines this history, highlighting a unique conjunction in the Netherlands of regional geomorphology, fishing traditions, palaeontological finds and museum collection-policies that goes back to the nineteenth century.

The history of these relationships begins in the estuary of the Scheldt River. This has long been confined between dykes to mitigate the threat of flooding, resulting in downcutting of deep pits into the underlying Pleistocene and prePleistocene geological strata and the recovery of animal fossils originating in these geological deposits. This was already attracting the attention of palaeontologists in the nineteenth century and soon resulted in the offer of payments to the fishermen of the Scheldt estuary to cast their nets into these deep pits to bring up more fossils. A formal relationship was established in the 1950s with the National Museum for Geology and Mineralogy in Leiden. This resulted in widespread publicity in cinema newsreels, the extension of 'bone fishing' to the North Sea with the introduction of more powerful boats and the beam trawl, an explosion in the number of discoveries, a community of private collectors feeding a commercial market in palaeontological fossils, and the creation of a journal, Cranium, with a respectable scientific reputation (Maarleveld, Chap. 27, this volume). These developments were taking place long before the creation of the UNESCO Conventions of 1982 and 2001. Many of the finds come from beyond the boundary of national territorial waters, and in any case, as Maarleveld notes, because they are palaeontological specimens, they also lie outside the jurisdiction of the 1970 UNESCO Convention on the Means of Prohibiting and Preventing the Illicit Import, Export and Transport of Ownership of Cultural Property.

Although these developments were concerned mainly with the collection of palaeontological specimens, the close connection between the National Museum for Geology and Mineralogy and the National Museum of Antiquities, also in Leiden, eventually led to the search for worked bone and antler in fishing expeditions, and many 
of these finds are in private collections, although it appears that this has not given rise to a commercial market. More recently, human bone specimens have been recovered, and the interest of collectors has extended to the search for stone and flint artefacts in the spoil from shellfish dredging or aggregates unloaded at Dutch harbours. A famous example of the latter is the recovery of a hand-axe from an aggregate load that could be traced back to the collection area and eventually led to the location and investigation of the A240 site in English territorial waters (Bailey et al., Chap. 10, this volume; Pater, Chap. 26 , this volume).

In recent years, the use of the beam trawl has been the subject of fierce discussions between marine ecologists and the industry because of the damage caused by widespread 'ploughing' of the seabed and the collection of everything in the path of the beam trawl, a process that also destroys the upper layer of any archaeological deposits, and attempts have been made to ban its use. Despite opposition to beam trawling and the availability of less destructive technologies such as the use of electrical pulses, the EU has recently ruled in favour of continued use of the beam trawl (as of February 2019, Maarleveld, Chap. 27, this volume).

The reality is that the large archive of palaeontological and archaeological material recovered by the Dutch fishing fleet would have been lost to science had it not been for the use of the beam trawl and the interest of private collectors. Even without information on the depositional context, these finds remain valuable as indicators of potentially undisturbed sites or zones of archaeological significance, as evidence for the available animals and terrestrial environments present on the now-submerged landscape and their exploitation by human communities, and a reminder of the incomplete nature of the on-shore record. Bone remains can also contribute valuable intrinsic information in themselves, such as evidence of bone pathologies in human remains and through direct application to individual specimens of radiocarbon dating, aDNA and stable isotope analysis (Peeters and Amkreutz, Chap. 8, this volume).
This long history of collection is also testament to a successful cooperation between industry and collectors, and a pointer to the ways in which future cooperation might evolve. Recovery of archaeological and palaeontological specimens in fishing nets and in the spoil from sand dredging and gravel extraction will likely continue as an incidental by-product of commercial activities if not an intentional activity, regardless of the regulations discussed above. And these finds will continue to provide valuable new information. Data on the location of finds has occasionally been recorded, and that is beginning to be applied more widely with benefits to the scientific interpretation of the finds and to the location of target areas worthy of future investigation or to be avoided or carefully managed in future offshore developments. New networks are also being formed to develop this collaborative agenda (Peeters and Amkreutz, Chap. 8, this volume).

\subsection{Blue Growth}

The concept of Blue Growth is the EU term for a phenomenon that is being recognised across the world, namely, the relative fragility of the marine and coastal environment and the huge demographic pressures that are being placed on it in a world where a major part of the population already lives along its coastlines and depends on its resources for employment and recreation, with all that this implies in terms of infrastructural development, tourism, employment opportunities and further population growth. It is also a zone that is uniquely vulnerable to climate change, being in the frontline of sea-level rise that is predicted for the coming centuries. The need for coherent planning informed by policies for the sustainable management of natural ecosystems and cultural resources in this heavily crowded strip of land and sea is paramount and has obvious relevance to the protection of the cultural heritage both on land and under water.

The EU's agenda for Blue Growth is set out in its 'Report on Blue Growth: Enhancing Sustainable Growth in the EU's Marine, Maritime Transport and Tourism Sector' date 7 June 2013 
(Danellis 2013). The document articulates the principles that have informed the maritime dimension of the Europe 2020 strategy and guidelines for financial investment. These include a recognition of the fragility of marine ecosystems, the likely role of the seas and oceans in future global economic growth, the importance of integrated management of all the activities focussed on the coastal zone-fisheries, tourism, transport, energy, biotechnology and mineral mining - and the value of regional centres of expertise and cross-border initiatives. Importantly in the context of the themes discussed in this volume, it calls for 'the uniform mapping of the seabed ... so that the information can be accessed by research centres, universities, and public institutions' and the development of 'plans to map and survey wrecked ships and submerged archaeological sites, which form an important part of the Union's historical and cultural heritage[and] the need to facilitate the understanding and study of such sites and help prevent the despoliation to which they are being subjected, thus enabling them to be properly preserved' (Danellis 2013, paragraphs 21 and 22, see also https://ec.europa. eu/maritimeaffairs/policy/blue_growth_en, accessed 16 June 2019 for updates).

It is too early to say what impact this agenda is having on the development of policies and investments in relation to the underwater cultural heritage, but the fact that $\mathrm{UCH}$ is explicitly on the EU agenda presents both an opportunity and a challenge to the research community and governmental heritage agencies working in collaboration to define how UCH should be defined, managed and monitored. The results reported in this volume and the companion volume of Flemming et al. (2017) form a step on the road to that next stage of development.

\subsection{Conclusions}

The overwhelming impression of this section is the multiple ways in which the growth of knowledge about submerged prehistory has evolved in concert with the expansion of industrial and commercial activity on the seabed and the develop- ment of international laws and regulations for the protection of the underwater cultural heritage. The present system of protection and regulation is by no means fool proof, and there remain gaps in coverage and the risk of illegal or unrecorded destruction of valuable information. Offshore industrial activity is inherently destructive or potentially so, but that is famously true of all excavation whether conducted by professional archaeologists to the highest current standards or by industrial dredging and bore holes, whether under water or on dry land. Moreover, industrial activities often expose deeply buried archaeological remains and land surfaces to discovery, and the spoil from offshore activities such as aggregate extraction can yield finds of intrinsic value even if the original context is no longer known. At the same time, the relationship with offshore industries can carry risks of complacency, of allowing the research agenda to be defined by the nature of the finds exposed during commercial activities, or of reliance on such activities for the discovery of remains from the deeper and less easily accessible areas of the continental shelf (Sturt et al. 2017). The complexities of the interplay between government regulation, commercial activity and scientific research will continue to provide both challenges as well as opportunities for new discoveries and the development of new research agendas. As Dromgoole (Chap. 25, this volume) emphasises, the key to further progress in these relationships lies in dialogue between developers, archaeologists and government agencies, voluntary agreements and codes of practice, and joint research initiatives, as much as in legislation.

\section{References}

Bicket A, Firth A, Tizzard L, Benjamin J (2014) Heritage management and submerged prehistory in the United Kingdom. In: Evans AM, Flatman JC, Flemming NC (eds) Prehistoric archaeology on the continental shelf: A global review. Springer, New York, pp 213-232. https://doi. org/10.1007/978-1-4614-9635-9_12

Danellis S (2013) Report on Blue Growth: Enhancing sustainable growth in the EU's marine, maritime transport and tourism sectors (2012/2297(INI)) Committee 
on Transport and Tourism, European Parliament, A7-0209/2013

Flemming NC, Cagatay MN, Chiocci FL, Galanidou N, Jöns H, Lericolais G, Missiaen T, Moore F, Rosentau A, Sakellariou D, Skar B, Stevenson A, Weerts H (2014) Land beneath the waves: Submerged landscapes and sea level change. A joint geosciencehumanities strategy for European continental shelf prehistoric research. Chu NC, McDonough N (eds) Position Paper 21 of the European Marine Board, Ostend, Belgium.

Flemming NC, Harff J, Moura D, Burgess A, Bailey GN (eds) (2017) Submerged landscapes of the European continental shelf: quaternary paleoenvironments. John Wiley \& Sons, Chichester

Glimmerveen J, Mol D, Post K, Reumer JWF, Van der Plicht H, De Vos J, Van Geel B, Van Reenen G, Pals JP (2004) The North Sea project: the first palaeontological, palynological, and archaeological results. In: Flemming NC (ed) Submarine prehistoric archaeology of the North Sea: research priorities and collaboration with industry. CBA Research Report 141. Council for British Archaeology, York, pp 43-52

Glimmerveen J, Mol D, Van der Plicht J (2006) The Pleistocene reindeer of the North Sea - initial palaeontological data and archaeological remarks. Quatern Int 142/143:242-246

Missiaen T, Pieters M, Maes F, Kruiver P, De Maeyer Ph, Seys J (2017) The SeArch project: towards an assessment methodology and sustainable management policy for the archaeological heritage of the North Sea in Belgium. In: Bailey GN, Harff J, Sakellariou D (eds) Under the sea: archaeology and palaeolandscapes of the continental shelf. Springer, Cham, pp. 415-424

Mol D, Post K, Reumer JWF, Van der Plicht J, De Vos J, Van Geel B, Van Reenen G, Pals J-P, Glimmerveen J (2006) The Eurogeul - first report of the palaeontological, palynological and archaeological investigations of this part of the North Sea. Quatern Int 142/143:178-185
Moree JM, Sier MM (eds) (2015) Interdisciplinary research programme Maasvlakte, vol 2. BOOR, Rotterdam

Peeters H, Murphy P, Flemming NC (2009) North Sea prehistory research and management framework (NSPRMF) 2009. RACM, Amersfoort

Salter E, Murphy P, Peeters H (2014) Researching, conserving and managing submerged prehistory: national approaches and international collaboration. In: Evans AM, Flatman JC, Flemming NC (eds) Prehistoric archaeology on the continental shelf: a global review. Springer, New York, pp 213-232. https://doi. org/10.1007/978-1-4614-9635-9_9

Satchell J (2013) Marine industry and submerged prehistoric archaeology. Published online at https://www. splashcos.org/sites/splashcos.org/files/downloads/ SPLASHCOS_Marine_Industry_Guide.pdf

Satchell J (2017) Education and engagement: developing understanding and appreciation of submerged prehistoric landscapes. In: Bailey GN, Harff J, Sakellariou D (eds) Under the sea: archaeology and palaeolandscapes of the continental shelf. Springer, Cham, pp 391-402

Sturt F, Dix J, Grant MJ (2017) The history of industry-linked research in English waters: lessons for the future. In: Bailey GN, Harff J, Sakellariou D (eds) Under the sea: archaeology and palaeolandscapes of the continental shelf. Springer, Cham, pp 425-436

Tidbury L, Satchell J, Momber G (2017) Arch-Manche: using archaeological, palaeoenvironmental, historic and artistic resources in coastal management. In: Bailey GN, Harff J, Sakellariou D (eds) Under the sea: archaeology and palaeolandscapes of the continental shelf. Springer, Cham, pp 403-413

Van Kolfschoten T, van Essen H (2004) Palaeozoological heritage from the bottom of the North Sea. In: Flemming NC (ed) Submarine prehistoric archaeology of the North Sea. Research priorities and collaboration with industry. CBA Research Report 141. Council for British Archaeology, York, pp 70-80

Open Access This chapter is licensed under the terms of the Creative Commons Attribution 4.0 International License (http://creativecommons.org/licenses/by/4.0/), which permits use, sharing, adaptation, distribution and reproduction in any medium or format, as long as you give appropriate credit to the original author(s) and the source, provide a link to the Creative Commons licence and indicate if changes were made.

The images or other third party material in this chapter are included in the chapter's Creative Commons licence, unless indicated otherwise in a credit line to the material. If material is not included in the chapter's Creative Commons licence and your intended use is not permitted by statutory regulation or exceeds the permitted use, you will need to obtain permission directly from the copyright holder.

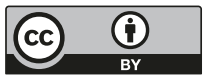

